\title{
Students' Metacognitive Thinking Process in Solving Covalent Bonding Problem Based on Academic Ability Level
}

\author{
H Aliyah*, Erman \\ Postgraduate Science Education Program \\ Universitas Negeri Surabaya \\ Indonesia \\ *E-mail: himatulaliyah16070795042@mhs.unesa.ac.id
}

\author{
B Sugiarto \\ Department of Chemistry \\ Universitas Negeri Surabaya \\ Indonesia
}

\begin{abstract}
This study was designed to identify and describe students' metacognitive thinking process of solving covalent bonding based on student academic ability level One hundred eight high school students in Indonesia participated in the study. Students are classified into upper, middle and lower academic groups based on field notes, student academic data, problemsolving test (TPM) score and teacher suggestions Six students consisting of two students in each group were interviewed to reveal their metacognitive thinking process. The data analysis technique used summative content analysis and tested for its validity by source triangulation. The results showed that the students' group of upper and middle academic ability are doing metacognitive thinking with dimensions of planning, monitoring, and reflection in solving covalent bonding problems, which the upper group has more varied metacognitive thinking process at monitoring and reflection dimensions. The lower group only do the planning and the monitoring dimensions. Therefore, teachers need to trace metacognitive in learning so that students are more careful in determining problem-solving strategies and obtain expected learning outcomes.
\end{abstract}

Keywords-metacognitive thinking process; covalent bonding; academic ability level

\section{INTRODUCTION}

Metacognition is defined as thinking about thinking or cognition about one's cognition [1-3]. Metacognition is concerned with thinking of students with their own ability to use certain learning strategies appropriately [4;5]. There are three dimensions of the metacognitive thinking process, which consists of planning, monitoring, and reflection [6-10]. It is important to know the metacognitive of a person because knowledge of his cognitive process can help one in choosing the right strategy for solving problems. In solving a problem, students need to be taught problem-solving steps to practice thinking skills so that various solutions are possible to solve the problem. These problem-solving steps are consistent with metacognitive skills.
Each student has different problem-solving strategies depending on the level of understanding he has, thus each student has different metacognitive skills in solving problems. Hoy said that because people differ in their metacognitive knowledge and skills, they differ in how well and how quickly they learn [8]. The metacognitive skills of students with higher academic ability than those with lower academic ability. High ability to solve problems with stages: develop planning, implementation monitoring, and action evaluation, whereas students with middle and lower ability solve problems given through the stages: develop planning, little monitoring implementation and little evaluation of action [11-15]

Covalent bonds are part of abstract chemical matter [16-18]. Abstract problem solving often confuses the students. The student's mistake or incompetence in solving the chemical problem is caused by an error in understanding the chemical concepts so that a sharp analysis of covalent bond problem solving is required. Metacognitive skills are one of the higher-order thinking skills needed in solving chemical problems [12, 20]. Based on the description above, this study aims to identify and describe the process of metacognitive thinking of students in solving covalent bond problems in terms of the level of academic ability.

\section{METHOD}

This research is a case study research with the qualitative descriptive approach. It is said descriptive qualitative because the data obtained in this study described in detail using words written or oral. Research data obtained from the results of the problem-solving test (TPM) and interview results.

One hundred eight high school students in Indonesia participated in the study. Data were 
collected in five stages. First, the researcher conducts the adaptation of the condition and environment of the teaching and learning activities in progress so as to obtain field notes that describe the students' activity and communication skills. Second, students do a problem-solving test (TPM) of covalent bonds to obtain a student's TPM score. Third, students are classified into upper, middle and lower academic groups based on field notes, student academic data, TPM score and teacher suggestions. Fifteen students consisting of five students in each group were interviewed to reveal their metacognitive thinking process. Finally, the data is tested for its validity by source triangulation.

The data analysis technique uses summative content analysis consisting of three stages: identifying and calculating the apparent metacognitive thinking process indicators, comparing the results of the subject with each other in the same group, and interpreting to obtain the metacognitive thinking process pattern of the student in solving the covalent bond problem. The metacognitive thinking process was identified based on metacognitive activity indicators adapted from Sugiarto [12].

\section{RESULTS}

Based on the analysis of the data, students' metacognitive thinking process of solving covalent bond based academic ability level be illustrated as shown in Table 1.

TABLE 1. Students' Metacognitive Thinking Process in Solving Covalent Bonding Problem Based on Academic Ability Level

\begin{tabular}{cccc}
\hline \multirow{3}{*}{ Indicators } & \multicolumn{3}{c}{ Academic Ability Level } \\
\cline { 2 - 4 } & Upper & Middle & Lower \\
\hline \multirow{4}{*}{ Planning } & $\mathrm{P}-1$ & $\mathrm{P}-1$ & $\mathrm{P}-1$ \\
\cline { 2 - 4 } & $\mathrm{P}-2$ & $\mathrm{P}-2$ & $\mathrm{P}-2$ \\
\cline { 2 - 4 } & $\mathrm{P}-3$ & $\mathrm{P}-3$ & $\mathrm{P}-3$ \\
\cline { 2 - 4 } & $\mathrm{P}-4$ & $\mathrm{P}-4$ & $\mathrm{P}-4$ \\
\cline { 2 - 4 } & $\mathrm{P}-5$ & $\mathrm{P}-5$ & $\mathrm{P}-5$ \\
\hline \multirow{3}{*}{ Monitoring } & $\mathrm{M}-1$ & $\mathrm{M}-1$ & $\mathrm{M}-2$ \\
\cline { 2 - 4 } & $\mathrm{M}-2$ & $\mathrm{M}-2$ & \\
\cline { 2 - 4 } & $\mathrm{M}-3$ & $\mathrm{M}-4$ & \\
\hline Reflection & $\mathrm{M}-4$ & & \\
\hline
\end{tabular}

Based on table 1, students' groups of upper, middle and lower academic abilities have metacognitive thinking process of planning dimensions with indicators: thinking/reading/writing what ones knows and does not know (P-1); determining goals (P-2); Determining the problem-solving strategies (P-3); Determining intermediate results that can be achieved (P-4); and planning representation (molecular formula/structure, reaction equation, text, etc) to support understanding ( $\mathrm{P}$ 5).

The activity of thinking/reading/writing what ones know and do not know (P-1) supported the idea form Gok said that subjects should decide what important information was on the problem and what information was required in the first step [22]. It was also in accordance with the opinion of Rysz which stated when a person read a problem, he could feel indirectly that he understood or did not understand what he read [23]. Here the aspect of metacognition related to individual knowledge was needed and through this stage people who resolved the evaluation would arrive in what he thought was also one aspect of the metacognitive experience.

Activity to determining goals (P-2) was supported the idea from Hamman that by doing writing meant the subject determined his attitude to plan what would be done, including the content/materials used as well as the source of knowledge [24]. Polya said that the thing which existed in problem-solving i.e. what was unknown, what data was available, what its terms, and so on are included in the stage of understanding the problem [25]. Pulmones included metacognition activities for the planning dimensions in problemsolving, might be in terms of thinking and writing what was known and what was known, as well as identifying where the place to find information that had not known yet [26].

Woolfolk argued that the determining of problemsolving strategies (P-3), what sources needed to be collected, how to begin, and which should be followed or implemented first were included in the metacognitive skills of planning in problem-solving [27]. According to Polya, the determining of problem-solving strategies ( $\mathrm{P}$ 3) aimed to find a relationship between one problem and another or the relationship between the data and the unknowing thing, and so on [25]. Jacob and Paris said that the component of cognition planning arrangements included setting goal, activating the relevant resources, and selecting the appropriate strategies [28].

Activity to determine intermediate results that can be achieved (P-4) and plan representation to support understanding (P-5) was supported the idea from SandiUrena that the activity in a problem-solving planning stage could be an allocation of resources and strategy selection [21]. Gok said that the subject had to simplify the problem by describing the situation using a simple diagram $r$ sketch of the object and expressing what they wanted to be found mathematically for certain quantity [22]. 
At the monitoring dimensions, metacognitive thinking process of the upper group includes indicators: repeatedly reading a material until one can understand (M-1); using rules such as: molecular formula/structure, equation, diagram and graph (M-2); Monitoring something that is considered error such as writing, drawing, molecular formula/structure and others (M-3); and monitoring carefully in problem solving (M-4). The middle group has monitoring dimensions with indicators: (M-1); (M-2); and (M-4). The lower groups have (M-1) and (M-2).

The above monitoring activities supported the idea from Hacker et.al, that a person who knew what was known and what was unknown was categorized into the cognition of the understanding of self-knowledge [29]. Monitoring was carried out during the activities problem-solving. This might be regarded as a selfevaluation or self-feedback during the learning process. If learners improved self-evaluation, awareness of the learning performance might become more apparent after each problem-solving. Furthermore, academic success could be affected by the learners; awareness about what strategies should be done for the context or content [30].

Rickey \& Stacy said that the learners who applied metacognition activity monitoring and regulatory dimensions/good thoughts setting could increase the success in resolving problem [31]. Pulmones said that monitoring activities were a manifestation of checking progress against goals or to do list dimension. The subject who did monitoring carefully meant that they use the memorized information as a learner's need which required important information to keep in mind [26].

The existence of these monitoring skills could deliver learners to control their own learning activities so that in the end they were able to learn the problemsolving process chemistry [32]. According to Schraw et.al that monitoring or regulating involved understanding and awareness of the successful completion of the task performance, including the self-testing inside [7]. Strategies that could assist learners in completing the learning task were very important. Learner's success depended on the ability to learn independently and monitoring their own learning so that learners should know the various learning strategies and when to use it with the right strategy. This consisted of the finding by Pulmones that the manifestation dimensions of metacognitive monitoring could be in terms of revisiting the problem, looking back at problem-solving, and checking progress against goals [26].
At the reflection dimensions, metacognitive thinking process of upper groups includes indicators: reflecting on the concepts/objectives have been achieved (R-1) and reflecting implementation/application more efficient strategy (R$2)$. The middle group has only (R-1), and no reflection by the lower group. According to Bound assessment or reflection was an activity in which a person recaptured the experience, thought about it again, reconsidered and re-evaluated it [1]. Someone who reflected or thought back to what he thought was not only good in the understanding of what he knew, but also could make his own decisions to consciously learn to correct mistakes, while Woolfolk explained that the decision-making activity included assessment of the process was generated by thinking and learning outcomes [27]. Research finding by Rahman et.al showed that the activity of reflection was able to increase the learners' metacognition ability [33]. However, the reflection was often not done because learners were less able to manage time during their study. It was within Rambush's opinion which stated that doing reflection in learning could take a lot of time [34].

\section{CONCLUSION AND RECOMMENDATION}

Based on the results, it can be concluded that students' group of upper and middle academic ability are doing metacognitive thinking with dimensions of planning, monitoring, and reflection in solving covalent bonding problems, which the upper group has more varied metacognitive thinking process at monitoring and reflection dimensions. The lower group only do the planning and the monitoring dimensions. Therefore, teachers need to trace metacognitive in learning so that students are more careful in determining problemsolving strategies and obtain expected learning outcomes

\section{REFERENCES}

[1] Gama, C.A., 2005. Integrating metacognition instruction in interactive learning environments (Doctoral dissertation, University of Sussex).

[2] Pierce, William, 2003, Metacognition: Study Strategies, Monitoring, and Motivation [Online].

http://academic.pgcc.edu/ wpeirce/MCCCTR/metacognition.htm

[3] Livingston, J.A. 1997. Metacognition: An Overview [Online]. http://gse.buffalo.edu/fas/shuell/cep564/metacog.htm

[4] Nur, M,. 1998. Teori-Teori Perkembangan. Surabaya: Institut Keguruan dan Ilmu Pendidikan Surabaya

[5] Coskun, Yelmiha. 2018. A Study Metacognitive Thinking Skills of University Students. In Journal of Education and Training Studies., 6 (3), $38-46$

[6] Jacobs, J. E., \& Paris, S. G. (1987). Children's metacognition about reading: Issues in definition, measurement, and instruction. Educational Psychologist, 22, 255-278 
[7] Schraw dan Moshman. 1995. Metacognitive Theories. Lincoln: University of Nebraska

[8] Hoy, Anita Woolfolk, 2005. Educational Psychology: Active Learning Edition Ninth Edition. United States of America: Person Education.

[9] Suratno. 2010. Pemberdayaan Keterampilan Metakognisi Siswa dengan Strategi Pembelajaran Jigsaw-Reciprocal Teaching (JIRAT). Jurnal Pendidikan. 17(2). 150-156

[10] Lefford and Thompson. 2018. Naturalistic artistic decision-making and metacognition in studio music. In Cognition, Technology \& Work. Advance online publication. DOI: https://doi.org/10.1007/s10111-018$\underline{0497-8}$

[11] Sudia. 2014. Profil Metakognitif Siswa SMP dalam Memecahkan Masalah Terbuka ditinjau dari Perbedaan Gender. Jurnal Pendidikan Matematika, 5(1), 38-51

[12] Sugiarto, Prabowo, and Suyono.2014. Students' Metacognitive SelfRegulation-A Case Study: Molecular Structure Problem Solving.Chemistry: Bulgarian Journal of Science Education. 23 (3): 374391

[13] Muhlisin, Ahmad. 2016. Analisis Keterampilan Metakognitif Ditinjau dari Kemampuan Akademik Berbeda Pada Perkuliahan Konsep Dasar IPA. Prosiding Seminar Nasional Biologi, Surabaya, 493-496

[15] Wardani. 2017. Analisi Metakognitif Siswa dalam Memecahkan Masalah Matematika Materi SPLDV Ditinjau dari Perbedaan Gender. Jurnal Mitra Pendidikan., 1(10), 1031-1045

[16] Pabuçcu, A. and Geban, Ö., 2012. Students' Conceptual Level of Understanding on Chemical Bonding. International Online Journal of Educational Sciences, 4(3). 563-580

[17] Özmen, H., 2004. Some student misconceptions in chemistry: A literature review of chemical bonding. Journal of Science Education and Technology, 13(2), 147-159.

[18] Peterson, R.F. and Treagust, D.F., 1989. Grade-12 students' misconceptions of covalent bonding and structure. Journal of Chemical Education, 66(6), p.459-460

[20] Azizah, U. and Nasrudin, H. 2018. Empowerment of Metacognitive Skills through Development of Instructional Materials on the Topic of Hydrolysis and Buffer Solutions. In Journal of Physics: Conference Series (Vol. 953, No. 1, p. 012199). IOP Publishing.
[21] Sandi-Urena. 2008. Design and Validation pf multi method assessment of metacognition and study of the effectiveness of metacognitive interventions (Dissertation). Clemson" Clemson University

[22] Gok. 2010. The General Assessmnet of Problem Solving Processes and Metacognition in Physics Education. . In Eurasian J. Phys. Chem. Educ 2(2): $110-122$.

[23] Rysz. 2004. Metacognitive in Learning Elementary Probability and Statictic. Disertation. Departement of Curiculum and Instruction: University of Cicinnati

[24] Hamman, L. 2005. Self-regulation in Academic Writing Tasks. International Journal of Teaching \& Learning in Hingher Education, 17(1). $15-26$

[25] Polya. 1973. How To Solve It. Second Edition. New Jersey: Princeton University Press.

[26] Pulmones. 2007. Learning Chemistry in Metacognitive Environmet, The Asia Pasific Educations Researches, 16(2). 165-183

[27] Woolfolk. 1998. Educational Psychology. Boston: Allyn and Bacon.

[28] Jbeili. 2012. The Effect of Cooperative Learning with Metacognitive Scaffolding on Mathematics Conceptual Understanding and Procedural Fluency. International Journal for Research in Education (IJRE).

[29] Harker, Dunlosky, and Graesser. 2009. Handbook of Metacognitive in Education. New York: Routledge.

[30] Sendudur, et. al. 2011. Metacognitive Awareness of Pre-Service Teachers. $2^{\text {nd }}$ International Conference on New Trends in Education and Their Implication. 27-29 April 2011, Antalya-Turkey.

[31] Rickey \& Stacy. 2000. The Role Of Metacognition In Learning Chemistry. Journal of Chemistry Education, 77, 915-920.

[32] Nbina \& Viko. 2010. Effect Of Instruction In Metacognitive SelfAssessment Strategy On Chemistry Students Self-Efficacy And Achievement. Academia Arena, 2(80, 34-43

[33] Rahman, Jumadi, Chaudry, Chisti \& Abbasi. 2010. Impact of Metacognitive Awarness on Performance of Students in Chemistry. Contemp. Isuess Educ. Res. 3(10), 39-44.

[34] Rambush, J. 2006. Situated Learning and Galperin's Notion of ObjectOriented Activity. Proceedings of the $28^{\text {th }}$ Annual Conference of the Cognitive Science Society. Mahwah: Lawrence Erlbaum. 